\title{
Engineering History and Heritage: Referees 2021
}

The following is a list of referees who have reviewed papers for Engineering History and Heritage between 1 December 2020 and 30 November 2021. The Institution of Civil Engineers is very grateful for their assistance.

We are continually looking for suitable reviewers for papers submitted to Engineering History and Heritage. Papers published in the Proceedings of the ICE must be submitted to at least two independent referees to judge accuracy, style, impact, importance and interest.

If you are interested in reviewing articles on any topic related to engineering history and heritage, please submit your name, qualifications or $\mathrm{CV}$, and

David Ashurst

Jorge Bernabeu Larena

David Broadbent

Dirk Buhler

Dennis De Witt

Willem-Jan Dirkx

\author{
Hamish Douglas \\ James Dow \\ Dario Foppoli \\ Donald Friedman \\ Dario Gasparini \\ William Hamilton
}

areas of expertise. We are in need of individuals who will agree to review papers in a timely fashion (within 3 to 4 weeks of receipt) and provide confidential feedback to the Editorial Advisory Panel concerning the quality of the paper and any suggested revisions that would be appropriate.

If you are such a person, please contact Rebecca Rivers (tel.: +44 (0)207 665 2241; e-mail: rebecca.rivers@icepublishing.uk) for more information on the referee process.

Bill Harvey
Marcis Kempe
Deborah Lazarus
Jose Martín-Caro
Thomas Morrison
Guinevere Nalder

